\title{
Deteksi Odontoglossum ringspot virus Terhadap Anggrek Alam di Hutan Wonosadi, Gunung Kidul
}

\author{
MAHFUT $^{1}$, BUDI SETIADI DARYONO ${ }^{2}$ \\ ${ }^{1}$ Jurusan Biologi, Fakultas Matematika dan Ilmu Pengetahuan Alam, Universitas Lampung \\ Jl. Prof. Dr. Soemantri Brodonegoro 1, Bandar Lampung 35145 \\ email: mahfutkariem@yahoo.com \\ ${ }^{2}$ Laboratorium Genetika, Fakultas Biologi, Universitas Gadjah Mada \\ J1. Teknika Selatan Sekip Utara Sleman Yogyakarta 55281 \\ email: bs_daryono@yahoo.com
}

\begin{abstract}
Wonosadi forest is managed forests by indigenous forest communities and is located in the hamlet of Duren and Sidorejo, Beji village, subdistrict Ngawen, Gunung Kidul regency, Yogyakarta. One of the biological richness contained in Wonosadi forest is very valuable natural orchids and need to be preserved. Management to the preservation of nature in the woods Wonosadi orchids can be done through natural orchid protection against infectious pathogens, including viruses. Odontoglossum ringspot virus (ORSV) is one type of orchid viruses infect most widely reported and has spread widely in the world, including in Indonesia. ORSV can cause severe damage to the orchid. Therefore, it is necessary to study to detect ORSV that infect wild orchids in the forest Wonosadi molecular basis for detecting the presence and pattern of infection ORSV as well as possible to reduce the severity of disease caused by infection with the virus. The purpose of this study is to assess the natural orchid ORSV infection in molecular Wonosadi forest that can be used as a database in an effort to protect against natural orchid Wonosadi forest. In the long term, the results of this study are very useful to support conservation efforts and determine appropriate conservation efforts for wild orchids in the forest Wonosadi. The initial phase of the study conducted a survey and collection of samples of wild orchids in the forest leaves that show symptoms of infection Wonosadi ORSV. Furthermore, molecular analysis performed with gene amplification Coat Protein ORSV using Reverse engineering Trancriptase-Polymerase Chain Reaction (RT-PCR).
\end{abstract}

Keywords: orchid soil, ORSV, RT-PCR, Wonosadi forest

\section{PENDAHULUAN}

Hutan Wonosadi merupakan hutan yang dikelola secara adat oleh masyarakat sekitar hutan dusun Duren dan dusun Sidorejo, Desa Beji, kecamatan Ngawen, kabupaten Gunungkidul. Hutan ini memiliki luas sekitar $25 \mathrm{Ha}$, yang tersebar di wilayah dusun Duren sebesar $15 \mathrm{Ha}$ dan sisanya $10 \mathrm{Ha}$ termasuk dalam wilayah dusun Sidorejo. Hutan Wonosadi terdiri dari zona inti dan zona penyangga. Pada zona inti diberlakukan aturan adat yang berupa larangan mengambil apapun yang ada di hutan Wonosadi, sedangkan pada zona penyangga dimanfaatkan masyarakat untuk penanaman tumbuhan kayu-kayuan (Aruni et al., 2010).

Karena merupakan hutan yang dikelola secara adat, hutan Wonosadi mendapatkan perhatian dan perlindungan dari masyarakat lokal di sekitarnya yang menyebabkan berbagai macam tanaman yang terdapat di hutan Wonosadi dapat tumbuh tanpa ada gangguan sehingga keanekaragaman hayati di dalamnya tetap terjaga. Salah satu kekayaan hayati yang terdapat di hutan Wonosadi adalah anggrek alam (Aruni et al., 2010). Menurut Comber (1990) dan Dressler (1993) anggrek yang dijumpai di hutan tumbuh secara alami dan cukup beragam, mulai dari anggrek tanah hingga anggrek epifit. Anggrek yang asli berasal dari hutan Wonosadi adalah anggrek tanah yang ditemukan di area terbuka yang memungkinkan adanya cahaya matahari langsung.

Anggrek tanah merupakan kekayaan alam yang sangat berharga dan perlu untuk 
dilestarikan. Adanya keanekaragaman anggrek tanah di hutan Wonosadi memerlukan adanya pengelolaan yang berkaitan dengan kelestarian dan konservasi yang pada akhirnya membantu pengembangan potensi anggrek alam tersebut (Purwantoro et al., 2005; Sun and Wong, 2001). Pengelolaan terhadap kelestarian anggrek tanah di hutan Wonosadi dapat dilakukan melalui perlindungan anggrek tanah terhadap infeksi patogen.

Salah satu jenis patogen yang menginfeksi anggrek, termasuk juga anggrek alam dan dilaporkan menimbulkan kerusakan dan kerugian secara ekonomis adalah virus (Sherpa et al., 2004). Salah satu virus yang dilaporkan paling banyak menginfeksi dan memiliki penyebaran yang luas di dunia termasuk di Indonesia adalah Odontoglossum ringspot virus (ORSV) (Wisler, 1989; Zettler et al., 1990; Sherpa et al., 2004). Oleh karena itu perlu dilakukan penelitian lebih lanjut yang berkaitan dengan deteksi ORSV yang menyerang anggrek alam di hutan Wonosadi secara molekular untuk mengetahui keberadaan dan pola penyakit serta sedapat mungkin mengantisipasi penyebaran penyakit akibat infeksi virus tersebut.

Penelitian ini dilakukan melalui deteksi ORSV sebagai antisipasi penyebaran infeksi virus tersebut sedini mungkin. Deteksi ORSV awal dilakukan dengan mengkoleksi sampel daun anggrek alam di hutan Wonosadi yang menunjukkan gejala terinfeksi ORSV. Analisis secara molekuler dilakukan untuk mengamplifikasi gen Coat Protein (CP) ORSV menggunakan teknik Reverse Transcriptase-Polymerase Chain Reaction (RT-PCR).

Hasil penelitian ini selanjutnya dapat digunakan untuk menentukan metode konservasi yang tepat yang mendukung upaya pelestarian dan perlindungan budidaya anggrek alam di hutan Wonosadi. Penelitian mengenai deteksi virus yang dilakukan pada anggrek alam di hutan Wonosadi dapat menjadi salah satu upaya potensial yang dapat mendukung pemilihan metode konservasi yang tepat melalui penerapan konsep basis data.

\section{METODE}

Survei dan Koleksi Sampel. Tahap pertama penelitian adalah melakukan survei dan koleksi sampel daun anggrek alam di hutan Wonosadi yang menunjukkan gejala terinfeksi ORSV berupa bercak-bercak mosaik dan klorotik pada daun. Gejala infeksi ORSV juga dapat berupa gejala laten, dimana tanaman terlihat sehat tetapi positif terinfeksi virus. Sampel daun tersebut disimpan dalam refrigerator pada suhu $-20^{\circ} \mathrm{C}$ sampai saat akan dianalisis.

Isolasi RNA. RNA virus diisolasi dari daun anggrek yang telah dikoleksi. Sampel daun dengan berat 0,1 gram ditimbang kemudian digerus hingga halus menggunakan mortar. Setelah halus, $1 \mathrm{ml}$ Redzol ditambahkan ke dalam mortar kemudian diaduk hingga merata. Campuran gerusan dan Redzol dituang ke dalam tube 1,5 $\mathrm{ml}$ kemudian dilakukan hand mixing sebanyak 50-100 kali (2-3 menit). Kloroform dingin $200 \mu 1$ ditambahkan kemudian divortex dan didiamkan selama 2-3 menit. Campuran disentrifugasi pada kecepatan $12.000 \mathrm{rpm} 15$ menit. Supernatan yang diperoleh diambil menggunakan pipet dan dituang ke dalam tube $1,5 \mathrm{ml}$ yang baru. Supernatan ditambahkan 200 $\mu 1$ etanol 70\% dingin dan dilanjutkan dengan hand mixing. Campuran dipindahkan ke dalam spin column $\left(\mathrm{SiMax}^{\mathrm{TM}}\right.$ membrane spin column) didiamkan selama minimal 3 menit. Campuran dalam column disentrifugasi pada kecepatan $12.000 \mathrm{rpm}$ selama 3 menit kemudian cairan yang tertampung di bagian bawah column dibuang. RNA washing buffer sebanyak $600 \mu \mathrm{l}$ ditambahkan ke dalam column dan disentrifugasi pada kecepatan $12.000 \mathrm{rpm}$ selama 1 menit. Cairan yang tertampung dibuang kemudian column disentrifugasi kembali pada kecepatan 12.000 rpm selama 2 menit. Column yang telah disentrifugasi dipindahkan ke dalam tube 1,5 $\mathrm{ml}$ yang baru lalu ditambahkan $50 \mu \mathrm{l}$ DEPC water dan didiamkan selama 2 menit. Sentrifugasi dilakukan kembali pada kecepatan $12.000 \mathrm{rpm}$ selama 2 menit sehingga diperoleh $50 \mu \mathrm{l}$ RNA dalam tube 1,5 $\mathrm{ml}$. Hasil isolasi disimpan pada suhu $-20^{\circ} \mathrm{C}$. 
Reverse Transcription-Polymerase Chain Reaction (RT-PCR). RNA hasil isolasi dilakukan RT dan PCR secara terpisah. Tahap
RT dilakukan menggunakan first strand cDNA synthesis kit dengan tahapan sesuai petunjuk yang disediakan oleh Thermo scientific.

Tabel 1. Urutan nukleotida primer gen Coat Protein $(C P)$ ORSV yang digunakan dalam RT-PCR (Lee and Chang, 2006)

\begin{tabular}{llll} 
Primer & Sequence 5'- 3' & Position & $\begin{array}{l}\text { Product } \\
\text { size }\end{array}$ \\
\cline { 1 - 2 } ORSV CP-F1 & ATGTCTTACACTATTACAGACCCG & CP gene 1-24 nt & \multirow{2}{*}{ 474 bp } \\
\hline ORSV CP-R1 & GGAAGAGGTCCAAGTAAGTCC & CP gene 474-454 nt &
\end{tabular}

Langkah pertama dalam RT adalah pencampuran $1 \mu \mathrm{l}$ RNA total hasil isolasi dengan $1 \mu 1$ reverse primer 100 pmol (CP-R1) dan water nuclease $10 \mu \mathrm{l}$ dalam tube $0,2 \mathrm{ml}$. Campuran disentrifugasi pada kecepatan rendah (spin down) untuk homogenasi. Denaturasi dilakukan pada suhu $65^{\circ} \mathrm{C}$ selama 5 menit kemudian dipindahkan ke dalam ice box berisi es batu dan ditambahkan bahan-bahan sebagai berikut:

Tabel 2. Komposisi bahan yang digunakan dalam proses RT

\begin{tabular}{llc}
\hline Komponen & Volume $(\mu \mathrm{L})$ & Konsentrasi \\
\hline $5 \times$ M-MLV Buffer & 4 & $10 \mathrm{mM}$ \\
\hline dNTPs & 1 & $10 \mathrm{U}$ \\
\hline Rnase & 0,25 & $100 \mathrm{U}$ \\
\hline 100 mM DDT & 2 & \\
\hline M-MLV Reverse Transciptase & 0,5 & (Thermo scientific)
\end{tabular}

Tube yang berisi campuran tersebut kemudian dihomogenasi dan diinkubasi dalam mesin masterthermal cycler pada suhu $37^{\circ} \mathrm{C}$ selama 60 menit, kemudian dilanjutkan dengan inkubasi pada suhu $96{ }^{\circ} \mathrm{C}$ selama 5 menit dan tabung dimasukkan kedalam ice box. Complementary DNA (cDNA) hasil RT dapat langsung digunakan dalam reaksi PCR. Tahap
PCR dilakukan dengan menggunakan PCR mix GoTaq ${ }^{\circledR}$ Green (Promega). Metode yang digunakan sesuai dengan petunjuk cara kerja yang direkomendasikan Promega. Untuk pelaksanaan proses PCR, dibuat campuran bahan dengan total volume $25 \mu \mathrm{L}$ di dalam tube $0,2 \mathrm{~mL}$. Komposisi bahan dalam proses PCR ditampilkan pada Tabel 3.

Tabel 3. Komposisi bahan yang digunakan dalam proses PCR

\begin{tabular}{lll}
\hline Komponen & Volume $(\mu \mathrm{L})$ & Konsentrasi \\
\hline Master Mix & 12,5 & $1 \mathrm{x}$ \\
\hline Primer $(C P$ ORSV $)$ & 3 & $0,1-1 \mu \mathrm{M}$ \\
\hline DNA Template & 3 & $10 \mathrm{pg}-1 \mu \mathrm{M}$ \\
\hline Nuclease free-water & 6,5 & \\
\hline Volume total & $25 \mu \mathrm{L}$ & (Promega) \\
\hline
\end{tabular}

Tube yang berisi campuran bahan-bahan tersebut selanjutnya dihomogenisasi. Formula tahapan dan siklus PCR yang digunakan dalam amplifikasi gen $C P$ ORSV ditampilkan pada Tabel 4.

Tabel 4. Tahapan dan siklus PCR yang digunakan dalam amplifikasi gen CP ORSV (Mahfut, 2010) 


\begin{tabular}{lcc}
\hline \multicolumn{1}{r}{ Reaksi } & Temperatur $\left({ }^{\circ} \mathrm{C}\right)$ & Waktu \\
\hline Predenaturation & 95 & 5 menit \\
\hline Denaturation & 95 & 30 detik diulang $34 \mathrm{x}$ \\
\hline Annealing & 50 & 45 detik \\
\hline Elongation & 72 & 1 menit \\
\hline Post-elongation & 70 & 10 menit \\
\hline
\end{tabular}

Elektroforesis Gel Agarosa. Proses preparasi sampel dilakukan dengan mencampurkan $5 \mu \mathrm{L}$ DNA produk PCR dengan $1 \mu \mathrm{L}$ loading dye di atas parafilm. Kemudian campuran DNA dimasukkan dengan loading dye kedalam sumuran. Gel agarose yang digunakan dalam penelitian ini adalah $2 \%$. Setelah semua sampel dimasukkan ke dalam sumuran. Kemudian hubungkan elektrode chamber mupid elektroforator dengan power supply pada tegangan $100 \mathrm{~V}$ selama 30 menit. Amati hasil running diatas UV transilluminator dan dokumentasikan.

\section{HASIL}

Survei dan Koleksi Sampel. Dari hasil survei penentuan lokasi pusat distribusi anggrek di hutan Wonosadi diketahui bahwa terdapat 3 lokasi yaitu Pelataran Ngenuman yang terdapat di dalam hutan, zona penyangga di bagian utara hutan, dan daerah perbukitan di luar hutan yang membatasi dengan pemukiman penduduk. Hasil pengamatan pada masing-masing lokasi diperoleh 3 spesies yang seluruhnya merupakan anggrek tanah, yaitu Pecteilis sussanae, Liparis sp., dan Spathoglottis sp.

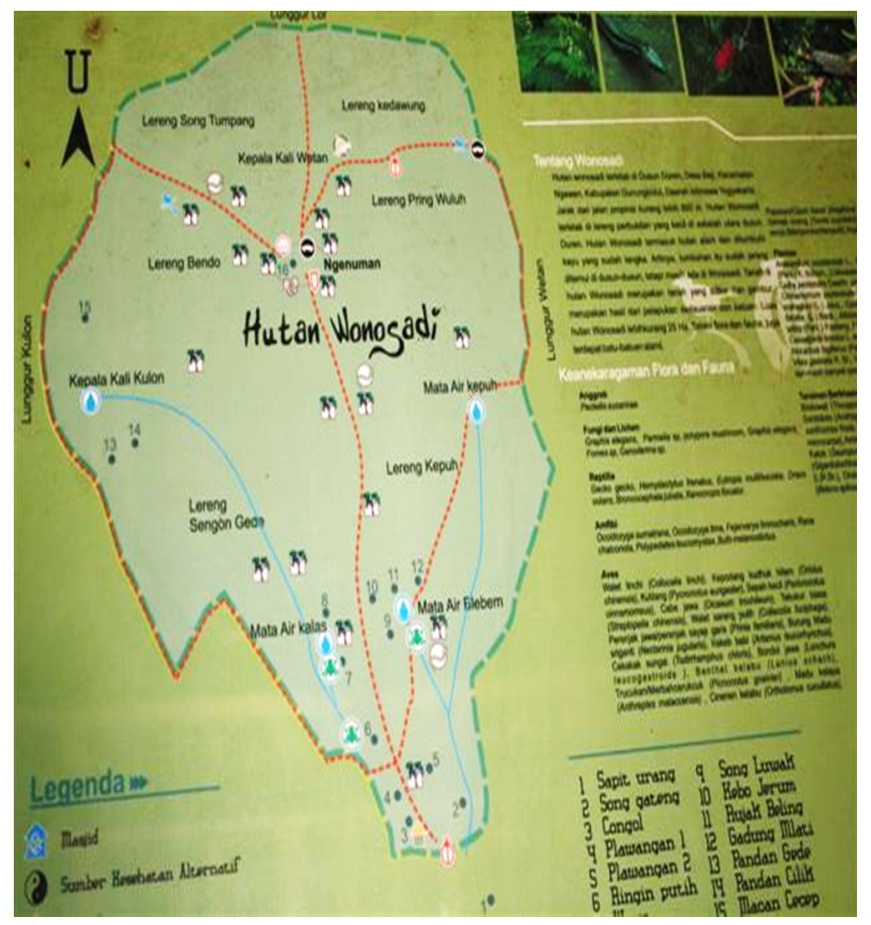

Gambar 1. Lokasi pengambilan sampel anggrek hutan Wonosadi 


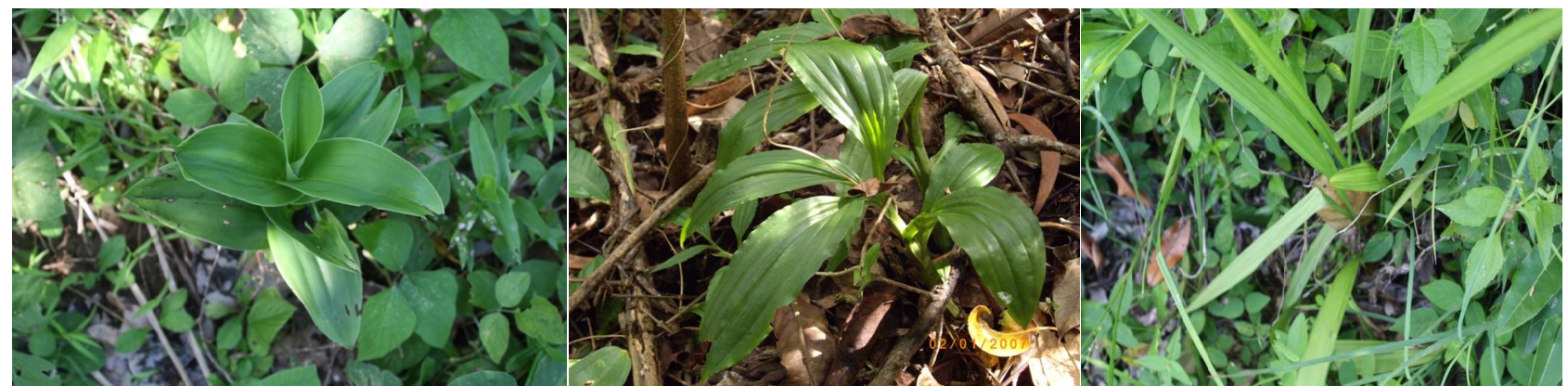

Gambar 2. Anggrek tanah yang ditemukan di hutan Wonosadi: (A). Pecteilis susannae (L.) Raf., (B) Liparis sp., dan (C) Spathoglottis sp.

Data hasil survei selanjutnya digunakan untuk tahap pengambilan sampel. Sampel yang dikoleksi adalah berupa daun anggrek alam yang menunjukkan gejala terinfeksi ORSV. Data koleksi sampel yang diperoleh disajikan pada Tabel 5.

Tabel 5. Data koleksi sampel daun anggrek alam dari hutan Wonosadi

\begin{tabular}{lll}
\hline Nama Spesies & Kode Sampel & Gejala Infeksi \\
\hline \multirow{2}{*}{ Pecteilis sussanae } & P1 & Nekrotik \\
\cline { 2 - 3 } & P2 & Nekrotik \\
\cline { 2 - 3 } P3 & Nekrotik, Mosaik \\
\hline \multirow{2}{*}{ Liparis sp. } & L1 2 & Nekrotik \\
\cline { 2 - 3 } Spathoglottis sp. & L3 & Nekrotik, Klorotik, Mosaik \\
\hline & S1 & Nekrotik \\
\hline & S2 & Klorotik \\
\hline
\end{tabular}

Berdasarkan data pada Tabel 5, diperoleh total 9 sampel dengan gejala infeksi ORSV yang berbeda. Badwen (1964) menjelaskan bahwa satu jenis virus dapat menimbulkan gejala yang berlainan pada tanaman yang berbeda, sementara virus yang berbeda dapat menyebabkan gejala yang hampir sama pada tanaman inang sama.

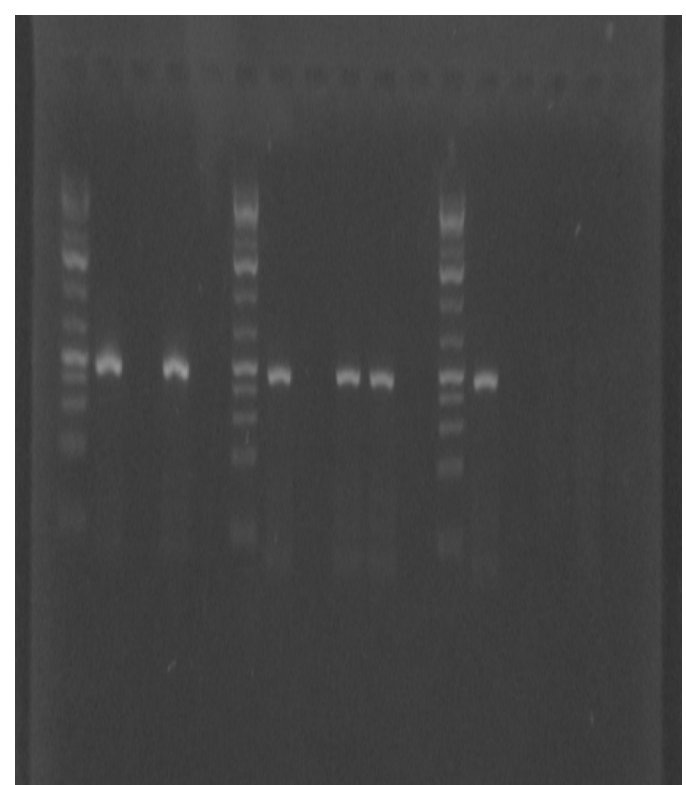

Gambar 3. Deteksi gen $C P$ ORSV dengan RT-PCR. $\mathrm{M}=$ marker $(100 \mathrm{bp}),+=$ kontrol positif, $-=$ kontrol negatif, dan L2 = Liparis $\mathrm{sp}$. 


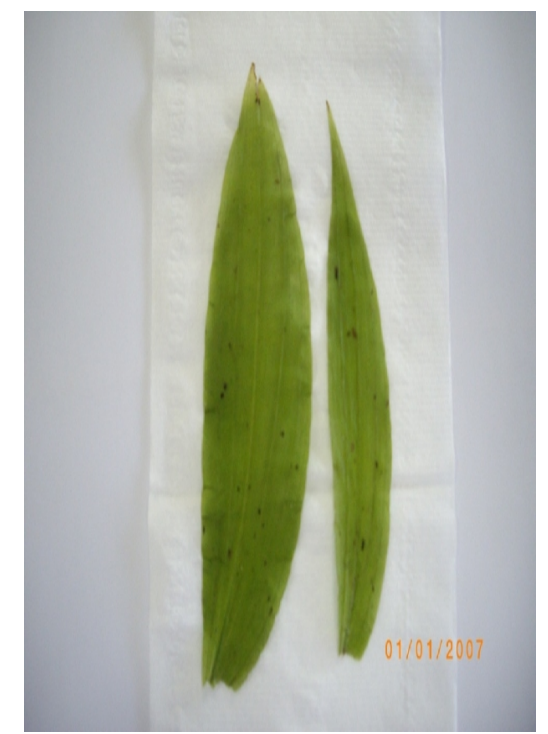

Gambar 4. Sampel daun Liparis sp. yang menunjukkan gejala terinfeksi ORSV

\section{PEMBAHASAN}

Gejala infeksi ORSV dari sampel yang dikoleksi di hutan Wonosadi adalah berupa nekrotik, mosaik, klorotik, dan curling leaf (daun menggulung). Purnomo (2006) menjelaskan bahwa nekrotik merupakan tipe gejala yang disebabkan oleh adanya kerusakan fisik atau kematian pada sel, bagian sel, atau jaringan. Beberapa gejala yang termasuk tipe nekrotik adalah bercak (necrose), busuk (rot), mati ujung (die back), dan kanker (kulit kayu mati mengering dengan batas yang jelas). Gejala lain, yaitu mosaik merupakan gejala infeksi ditandai dalam bentuk "pulau-pulau hijau" (green islands) dimana terjadi pencampuran bagian daun yang berwarna kuning atau hijau muda dengan warna hijau (Akin, 2006). Gejala klorotik adalah tipe gejala yang disebabkan kerusakan kloroplas yang mengakibatkan bagian-bagian tanaman yang dalam keadaan normal berwarna hijau menjadi menguning. Kerusakan kloroplas dapat disebabkan oleh kurang atau tidak terbentuknya klorofil akibat racun patogen, kekurangan mineral, pencemaran udara, kekurangan air, atau karena bahan kimia. Gejala klorotik sering mendahului gejala nekrotik sehingga lama-kelamaan berwarna coklat. Terkadang gejala klorotik sering berasosiasi dengan nekrotik dimana klorotik mengelilingi nekrotik yang disebut "halo" (Purnomo, 2006). Sedangkan curling leaf merupakan gejala malformasi daun yang memperlihatkan perubahan bentuk pada tepi daun berupa menggulung (curling).

Berdasarkan deteksi RT-PCR diketahui bahwa virus ORSV terbukti telah menginfeksi anggrek alam di hutan Wonosadi. Hal ini ditunjukkan dengan adanya fragmen DNA spesifik dari gen $C P$ ORSV pada ukuran 474 bp, seperti ditampilkan pada Gambar 3. Sampel L2 merupakan sampel daun anggrek Liparis sp. yang dikoleksi dari lokasi 2 yaitu zona penyangga. Sampel ini merupakan satusatunya sampel positif terinfeksi ORSV dengan gejala berupa nekrotik, klorotik, dan mosaik seperti terlihat pada Gambar 4.

Sampel L2 juga merupakan satu-satunya sampel yang menunjukkan gejala infeksi terparah jika dibandingkan dengan sampel lainnya. Gejala infeksi ORSV memang tidak selalu spesifik untuk tiap jenis tanaman, bahkan beberapa sampel lain yang menunjukkan gejala infeksi ORSV tetapi ternyata tidak positif terinfeksi. Hal ini sangat dimungkinkan karena gejala infeksi yang muncul tersebut merupakan gejala yang ditimbulkan oleh virus atau patogen lain seperti bakteri dan jamur yang seringkali berasosiasi dan memunculkan gejala seperti terinfeksi ORSV.

Penelitian mengenai deteksi ORSV terhadap anggrek alam di hutan Wonosadi dapat menjadi salah satu upaya potensial yang dapat mendukung penerapan konsep konservasi anggrek alam melalui upaya 
perlindungan tanaman. Penerapan konsep konservasi dapat dilakukan dengan mengetahui cara mengenali gejala infeksi dan sedapat mungkin mencegah penyebaran penyakit anggrek yang disebabkan oleh virus sehingga keberadaan anggrek anggrek alam yang sangat berharga dapat terjaga kelestariannya.Perkembangan teknologi dalam upaya perlindungan anggrek terhadap infeksi ORSV sampai saat ini belum banyak memberikan hasil yang baik. Beberapa usaha seperti produksi anggrek yang tahan ORSV atau pembuatan plant vaccine memiliki tingkat keberhasilan hanya sebatas laboratorium saja. Sehingga kegiatan konservasi melalui upaya perlindungan ini membutuhkan kerjasama dari berbagai pihak termasuk para peneliti dan pengelola tanaman anggrek. Proses perlindungan sederhana yang masih umum dilakukan adalah dengan memisahkan tanaman yang sehat dan sakit sehingga terjadi kontak langsung antara keduanya. Seperti diketahui bahwa ORSV termasuk ke dalam TMV yang dapat menyebar melalui kontak dengan tanaman sakit. Selain itu, eradikasi melalui pemusnahan tanaman dengan cara dibakar termasuk sterilasi tanah dan pot dari tanaman sakit terbukti cukup efektif untuk menghentikan penyebaran virus ini.

\section{KESIMPULAN}

Dari penelitian yang dilakukan dapat diketahui bahwa pada beberapa populasi anggrek alam di hutan Wonosadi telah ditemukan infeksi ORSV yang ditunjukkan oleh gejala-gejala tertentu. Adanya infeksi tersebut sangat dipengaruhi oleh keadaan lingkungan hutan serta cara adaptasi virus secara alami.Melalui penelitian deteksi ORSV terhadap anggrek alam di hutan Wonosadi ini diharapkan dapat menjadi salah satu upaya potensial yang dapat mendukung penerapan konsep konservasi anggrek alam melalui upaya perlindungan tanaman.

Perlu dilakukan upaya lanjut mengenai pengembangan penanganan terhadap ORSV yang menginfeksi anggrek alam di hutan Wonosadi, antara lain pengenalan gejala infeksi virus secara dini dan pencegahan penyebaran virus tersebut.

\section{UCAPAN TERIMAKASIH}

Penelitian ini dilaksanakan atas biaya dana I-MHERE B.2.c. Fakultas Biologi UGM, sesuai dengan nota kesepakatan nomor: UGM/BI/1156/I/05/04, tanggal 6 April 2010.

\section{DAFTAR PUSTAKA}

Aruni DK, Abdullah S, Setiadi BS, Mahfut. 2011. Study on Genetic Diversity and Convervation of Orchids in Wonosadi Forest, Gunung Kidul Based on Molecular Analysis. Prosiding Seminar. International Conference on Biological Science: Advances in Biological Science. September $23^{\text {rd }}-24^{\text {th }}$ 2011. Yogyakarta: Fakultas Biologi Universitas Gadjah Mada.

Akin HM. 2006. Virologi Tumbuhan. Yogyakarta: Kanisius. hal 449-469.

Lee SC and Chang YC. 2006. Multiplex RTPCR Detection of Two Orchid Viruses with an Internal Control of Plant nad5 mRNA. Plant Pathol. Bull. vol 15:187196.

Mahfut. 2011. Deteksi dan Karakterisasi Molekuler Odontoglossum ringspot virus (ORSV) Isolat Jawa dan Bali. [Tesis]. Yogyakarta: Universitas Gadjah Mada.

Purnomo B. 2006. Konsep Ilmu Penyakit Hutan. Malang: Fakultas Pertanian Univeristas Brawijaya. hal 1-9.

Comber JB. 1990. Orchid of Java. London: Bentham-Moxon Trust. Royal Botanic Garden, Kew.

Dressler RL. 1993. Phylogeny and Classification of The Orchid Family. Melbourne: Cambridge University Press. pp 125-211.

Purwantoro A, Ambarwati E, Setyaningsih F. 2005. Kekerabatan Antar Anggrek Spesies Berdasarkan Sifat Morfologi Tanaman dan Bunga. Ilmu Pertanian. vol 12 (1): 1-11.

Sun M, and Wong KC. 2001. Genetic Structure of Three Orchid Species with Contrasting Breeding Systems Using RAPD and Allozyme Markers. American Journal of Botany. vol 88(12): 2180-2188.

Sherpa AR, Hallan V, Zaidi AA. 2004. Cloning and sequencing of coat protein 
gene of an Indian Odontoglossum ringspot isolate: Acta Virol. vol 48: 267-269.

Wisler GC. 1989. How to Control Orchid Viruses: The Complete Guidebook. Gainesville, Florida: Maupin House Publishers. pp 119.
Zettler FW, Ko NJ, Wisler, GC, Elliot MS. and Wong SM. 1990. Viruses of orchids and their control. Plant Dis. vol 74: 621-626.

Bawden FC. 1964. Plant Viruses and Virus Diseases. New York: Ronald Press. pp 222-240. 